\title{
Some factors influencing peak yield and days attain to peak yield in Friesian cattle in the central region of Iraq
}

\author{
K.N. Taher \\ Coll. of Vet. Med./ Unive. of Al-Qadysia
}

\begin{abstract}
This study was under taken on 950 lactation records kept at Iraq-Jordinian company / Dujaila- Wasit Governorate during a period from 2001-2003.to evaluate the effect of some nongenetic factors (age at $1^{\text {st }}$ calving,parity,season of calving, year of calving and service period ) on peak milk yield and days to attain peak yield .The least-squares means for peak milk yield and days to attain peak yield were $: 14.252 \pm 4.763 \mathrm{~kg}$ and $47.528 \pm 24.121$ days.Peak milk yield was significantly influenced $(\mathrm{p}<0.05)$ by season and year of calving $(\mathrm{p}<0.01)$. Days to attain peak yield was significantly $(\mathrm{p}<0.05)$ influenced by year of calving.
\end{abstract}

\section{Introduction}

Milk yield refers to the quantitative out put of milk by animal during a session of milking .It is express in various forms: Lactation milk yield, or function there of attributed to the lactation curve such as persistency, peak milk yield and days to peak yield (1,2,3).Lactation cure are important in management decisions making processes and genetic analysis $(4,5)$. Knowledge of the probable shape of the lactation curve makes feeding trails more efficient because differences among treatments are more easily detected when the animals were grouped according to the expected curve shape $(6,7)$. If genetic aspects of the shape of the lactation curve can be determined and then represented through mathematic model, selection for these traits may result in improved yield efficiency .Because of very few studies have been reported earlier regarding the non-genetic factor affecting these important traits in Iraq. An attempt has been made in the present investigation to study the effect of age at $1^{\text {st }}$ calving, party ,season of calving ,year of calving and service period on the peak milk yield and days to peak yield.

\section{Materials and Methods}

This work was carried out on 950 lactation records maintained at IraqJordinian company /Dujaila- Wasit Governorate during a period 2001-2003. The data were edited to remove records of lactations following abortion, lactation with missing test day yields and lactations with in consistent dates of birth ,calving and drying. The statistical analysis used in this study was the least squares method described by (8).To test different comparison among levels of factors used method explained by (9). Peak yield was taken as the highest daily records tested at monthly intervals according to the following model:

$$
\text { Yijklm }=\mu+\mathrm{Ai}+\mathrm{Pj}+\mathrm{Cs}_{\mathrm{k}}+\mathrm{Cy}_{\mathrm{L}}+\mathrm{b}\left(\mathrm{Xijklm}^{-} \mathrm{X}^{-}\right)+\text {eijklm }
$$

Where Yijklm $=$ is the trait .

$\mu=$ is the overall mean

$\mathrm{Ai}=$ is the effect of age at $1^{\text {st }}$ calving ( $i=1,2$ and 3 ).

$\mathrm{Pi}=$ is the effect of parity $(\mathrm{j}=1$ and 2$)$.

$\mathrm{Cs}_{\mathrm{k}}=$ is the effect of season of calving $(\mathrm{k}$ $=1,2,3$ and 4).

\section{Results and Discussion}

The least-squares means for different factors influencing peak milk yield and days to attain peak yield are presented in(Table 1). The average peak milk yield and days to attain peak yield were $14.252 \pm 4.763 \mathrm{~kg}$ and $47.528 \pm 24.121$ days. The results obtained by the present study was lower than those
$C y_{L}=$ is the effect of year of calving ( $\mathrm{L}=1,2$ and 3 ).

$b=$ is the partial regression coefficient of trait studied on length of service period.

eijklm $=$ is a random effect peculiar to the ijklm ${ }^{\text {th }}$ trait with an expected value of zero and variance $6{ }^{2}$.

reported by (10). The effect of age at $1 \mathrm{st}$ calving ,parity, season of calving, year of calving and service period are shown in (Table 2)as follow:

- Age at $1^{\text {st }}$ calving: Age at $1^{\text {st }}$ calving had no significant effect on peak yield and days to peak yield,younger cows (21-24 month)at 
1st calving tend to attain lower peak yield at shorter period after calving than older cows. These results were in contrast with (11).

- Parity:The effect of parity on both traits was non-significant, Although cows with second lactation characterized with late and high peak yield as compared to cows with first lactation. This result was disagreement with $(6,12,13)$.However .Tekerli etal (10) reported that the lowest peak yield $(26.6) \mathrm{kg}$ during first lactation as compared to $(30.5) \mathrm{kg}$ during the later lactation, the increase in peak yield with advanced age of cows may be due to the development of mammary gland and other body systems due to recurring pregnancies and lactations.

-Season of calving:The effect of calving season on peak milk yield was significantly $(\mathrm{p}<0.05)$ and found no significant on days to peak yield .The highest peak yield was associated with cows that calving during spring (18.866 \pm 6.642$) \mathrm{kg}$ and the lower peak milk yield was to the cows calved in autumn
$(11.095 \pm 0.95) \mathrm{kg}$.The relation between peak yield and calving season may result from increasing temperature and decreasing food especially in summer, similar findings were obtained by (10.12).

- Year of calving: The present study reveals that year of calving had a highly significant $(\mathrm{P}<0.01)$ effect on peak yield and significant $(\mathrm{P}<0.05)$ on days to peak yield .The significant effect of calving year may be explained by the variation in environmental conditions and management as well as annual climate changes .This results are in accordance with results reported by $(6,10)$.

- Service period: The results shown in table (2) reveals that anon-significant effect of service period on both traits studied .This could be attributed to the fact that neither peak milk yield nor days to peak yield were under the effect of pregnancy as service period .These results similar to that reported by (10).

Table -1- Least-squares means and standard errors of non-genetic factors effect of peak yield and days to peak yield .

\begin{tabular}{|c|c|c|c|}
\hline Classification & No & Peak milk yield $(\mathrm{kg})$ & Days to peak yield (day) \\
\hline $\begin{array}{l}\text { Over all mean } \\
\text { Age at } 1^{\text {st }} \text { calving } \\
\text { (month) }\end{array}$ & $\begin{array}{l}950 \\
250 \\
540 \\
160\end{array}$ & $\begin{array}{l}14.252 \pm 3.510 \\
12.415^{\mathrm{a}} \pm 6.364 \\
13.873^{\mathrm{a} \pm} 7.473 \\
16.468^{\mathrm{a}} \pm 5.561\end{array}$ & $\begin{array}{l}47.528 \pm 19.121 \\
43.733^{\mathrm{a}} \pm 22.540 \\
46.084^{\mathrm{a}} \pm 24.191 \\
52.767^{\mathrm{a}} \pm 18.326\end{array}$ \\
\hline $\begin{array}{r}\text { Parity } \\
1 \\
2\end{array}$ & $\begin{array}{l}698 \\
252\end{array}$ & $\begin{array}{l}13.166^{\mathrm{a}} \pm 3.520 \\
15.338^{\mathrm{a}} \pm 6.425\end{array}$ & $\begin{array}{l}43.883^{\mathrm{a}} \pm 20.083 \\
51.173^{\mathrm{a}} \pm 21.914\end{array}$ \\
\hline $\begin{array}{l}\text { Season of calving } \\
\text { Dec-Feb } \\
\text { Mar-May } \\
\text { June-Aug } \\
\text { Sept-Nov }\end{array}$ & $\begin{array}{l}90 \\
400 \\
310 \\
150\end{array}$ & $\begin{array}{l}14.201^{\mathrm{a}} \pm 8331 \\
18.846^{\mathrm{a}} \pm 4.821 \\
11.095^{\mathrm{b}} \pm 5.222 \\
12.866^{\mathrm{b}} \pm 2.441\end{array}$ & $\begin{array}{l}49.066^{\mathrm{a}} \pm 19.784 \\
56.098^{\mathrm{a}} \pm 17.771 \\
44.856^{\mathrm{a}} \pm 15.321 \\
40.092^{\mathrm{a}} \pm 13.363\end{array}$ \\
\hline $\begin{array}{l}\text { Year of calving } \\
2001 \\
2002 \\
2003 \\
\begin{array}{l}\text { Regression on service } \\
\text { period }\end{array}\end{array}$ & $\begin{array}{l}305 \\
210 \\
435 \\
----\end{array}$ & $\begin{array}{l}15.762^{\mathrm{a}} \pm 4.320 \\
14.889^{\mathrm{a}} \pm 7.423 \\
12.105^{\mathrm{b}} \pm 2.345 \\
0.036 \pm 0.028\end{array}$ & $\begin{array}{l}56.111^{\mathrm{a}} \pm 22.421 \\
46.794^{\mathrm{a}} \pm 18.342 \\
39.679^{\mathrm{a}} \pm 10.221 \\
-0.197 \pm 0.189\end{array}$ \\
\hline
\end{tabular}


Table-2- Analysis of variance for various factors affecting peak yield and days to peak yield

\begin{tabular}{|l|c|l|c|}
\hline \multirow{2}{*}{ Source of Variance } & \multirow{2}{*}{ df } & \multicolumn{2}{|c|}{ Mean Squares } \\
\cline { 3 - 4 } Age at $1^{\text {st }}$ calving & 2 & 12500.847 & Days to peak yield \\
Parity & 1 & 561.466 & 33265.1 \\
Season of calving & 3 & $22441.771^{*}$ & 4700.686 \\
Year of calving & 2 & $63698.631^{* *}$ & 548937.965 \\
Regression on service & 1 & 8804.688 & $1724512.189^{*}$ \\
period & 940 & 8646.469 & 396801.310 \\
Residue & 949 & & 412.766 .348 \\
\hline Total & & & \\
\hline
\end{tabular}

$* \mathrm{p}<0.0 .5$

$* * \mathrm{p}<0.01$

\section{References}

1.Farhanfar,H.,and Rowlinson, P. 2007. Genetic analysis of wood's Lactation curve for Iranian Holstein heifers. J.Biol. Sci., 7:127-135.

2.Mark, T. 2004. Applied genetic evaluations for production and functional traits In dairy cattle.J.Dairy Sci.,87:87:26412652.

3.Leclerc,H.,Duclos,D.,Barbat,A.,Druet,T., and Ducrocq,V. 2008. Environmental effects on lactation curve included in a testday model genetic evaluation. Animal,2:344-353.

4.Macciotta ,N.P.P.,vicario D., and cappioborlino, A. 2005. Detection of different shapes of lactation curve for milk yield in dairy cattle by empirical mathematical models. J.Dairy Sci, 88:1178-1191.

5.Silvestre,A.M,petim-Batista. ,F., and Colaco,J.2006.The accuracy of seven mathematical functions in modeling dairy cattle lactation curves based on test-day records

from varying samples schemes J.Dairy Sci. , 89:1813-1821.

6.Rao,M.K., and Sundaresan ,D.1979. Influence of environment and heredity on the shape of lactation curve in Sahiwal cows. J. Agric. Sci. Cambridge., 92:393-401.

7.SÖlkner, J. and Fuchs. 1987. A comparison of different measures of persistency with special respect to variation of day milk yield .Livest.Prod.Sci,16:305319.

8.Harvey, W.R.1987.User' s guide for LSMW PC-1 Version ,Mixed model least-squares and maximum likelihood computer program. Mimeo.ohio state uni., Columbus.

9.Duncan ,D.B.1955.Multiple range and multiple $\mathrm{F}$ test .Biometrics,11:142.

10. Tekerli, M.,Akinci,Z.,Dogan ,I.and Akcon,A.2000.Factors affecting the shape of lactation curve of Holstein cows from the balikesir province of Turkey. J.Dairy Sci,83:1381-1386. 
11. Wasike, C.B., Mogthe, T. M., Kali, A. K. and peter,k.j.2010.Non-genetic sources of variation in lactation curve traits of dairy cattle in Kenya. East African Agricultural and Forestry Journal, 76:855-859
12. Keown,J.F., Evertt,R.W., Empet, N. B. and wadell,L.H.1986.lactation curve., J.Dairy sci,69:769-781.

13. Singh,J. and Shukla ,K.P.1985.Factors affecting persistency of milk production in Gir cattle .Indian Vet.J,62:888-894.

\section{بعض العوامل المؤثرة على قمة إنتاج الحليب والوقت اللازم للوصول إلى قمة المّة

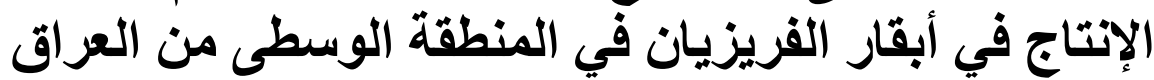 \\ كريم ناصر طاهر المنطرة \\ كلية الطب البيطري/ جامعة القادية

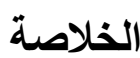

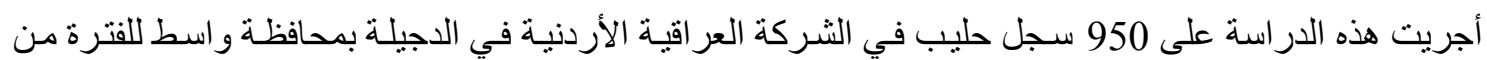

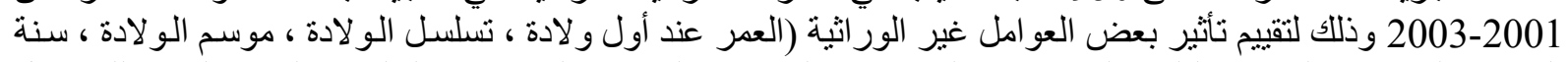

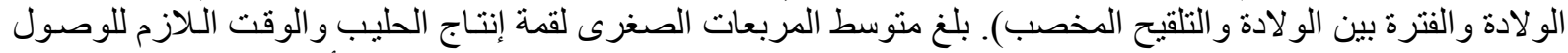

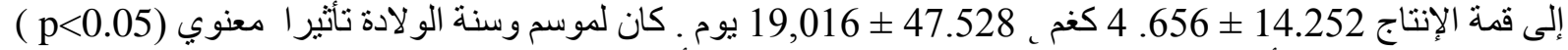

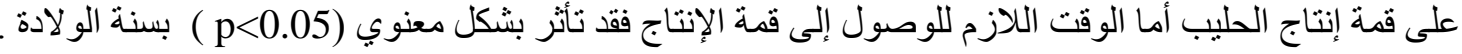

